\title{
20 Moving from fashions to a continuous stream of change: teacher development and IT
}

\author{
Anna Kristjánsdóttir \\ Kennaraháskóli Íslands \\ Reykjavik, Iceland
}

\begin{abstract}
Teacher development has existed for a long time and in history there are excellent examples of teachers who have continuously sought deeper knowledge and wider perspectives through their own study and participation in a community of colleagues. On the other hand 'Teacher Development (TD)' as a concept has come up more recently and is in fact interwoven with the rise and rapid growth of IT in education. One can say that TD in this respect is both a result of IT and a pre-requisite for a quality in the use of IT in education.
\end{abstract}

\section{Keywords}

Open learning, teacher education, self-assessment, transfer, attitudes, collaborative learning.

\section{Background}

The road of IT when it comes to mathematics teaching is paved with fashions; the fashion of programming, of CAL, of user software like spreadsheets, of electronic communication and now the fashion of browsing the web to name some. Fashions are good in some ways. They offer the scene to new people who have not been in the arena and can thus seize the opportunity to jump in and contribute, often with unforeseen insight. But fashions are not good in every sense. When they disappear they do that sometimes abruptly and leave no space for the parts of it that were of quality and are worth preserving. They are dismissed because there exist no frame for measuring the long-time appropriateness or to ensure the lasting influence.

The wave of IT has left none of the schools I know untouched. Hardware and software have been on the agenda and practical problems of placing the equipment have been solved in the best way for different circumstances. But IT, as influencing the subjects and giving an integrated basis for the subjects, generally is still outside the reach of too many teachers. And it will continue to be so if focus is not changed. The focus has been on the new perspectives, on IT itself, on particular pieces of software, or a good know-how in limited areas. But 
the focus has not been on the content, method and basis for teaching which were the dominating factors before the information age. These 'default values' have to move under the microscope again if threads from 'what was' to 'what is' are to be found by each and every teacher.

Our times are indeed both demanding and exciting for teachers. In fact there are hopes that now teaching may truly become and be respected as a profession. But surely there are many blocks on the road. The background of mathematics teachers has rarely been an integrated one: 'The pervasive lack of genuine cooperation between [professors of education and academic mathematicians] further weakens the professional status of mathematics teachers' (Noddings, 1992, p.198). Or the demands made on them when electronic means overtake: 'How can they be sure that what is to be learned is indeed learned? For what can they be held accountable? ... Where will they find satisfactory alternative to the security of the text? If not direct leadership in the classroom, then wherein lies their expertise?' (Black and Atkin, 1996, p.121). With the growth of mathematics education as a field of research we have the basis to deal with these problems and hopefully change the situation gradually.

\section{The changing roles of learners and teachers}

One of the important features that comes up very clearly through the research in mathematics education is support for a stronger focus on the nature of the learner and the learner's past and present experiences: 'Each person has at any given time a private reality, a private realm of the meaningful. To teach someone is to extend this reality, to enlarge it.' (Shenitzer, 1981, p.95). Some teachers have paid attention to this aspect of teaching and learning, but usually intuitively and without any substantial arguments supported by research and theory. The situation here has also changed, not only for pupils, but also for teachers and TD: 'What teachers internalise from their teacher education experiences is a function of their experiential world, not that of the teacher educator' (Cooney, 1994, p.10). With the powerful media of modern times and breaking down of the school walls, it is extremely important to take these ideas into consideration and work accordingly.

Many problems turn up which people, at large, were not aware of, thinking of them as simple facts, and some of these problems are very intriguing: 'Over the past 20 years there has been a continuing dialogue in mathematics education which is attempting to make clearer the 'vague concept' of mathematical understanding.' (Kieren, 1994, p.213). And to another problem, one can take the seemingly most simple offspring of the information age, the calculator, which in the mind of a large group of teachers, parents and politicians causes a threat to mental arithmetic and should therefore abolished. But very few of these people seem to have the historical span and insight to remember that there has always been another threat to mental arithmetic: 'Mental arithmetic is the original way of calculating. Man calculated mentally long before the invention of numerals. It is tragically observed that as the result of the teaching of arithmetic, people 
frequently cannot even calculate with low numbers without having pencil and paper at hand' (Finnbogason, 1903, p.93)

Ways are clearly needed to confront frequently unspoken attitudes and opinions. This must be done with care and in a naturally constructive environment. And because of the powerful influence of IT everywhere in the society it is important that this is not done in 'layers' as has been the traditional way of teaching, i.e., pupils as a group, preservice students as a group, teachers as a group, teacher educators and other academics as one or many groups. Instead mixed groups, of an appropriate working size, cutting through the layers are much better suited to deal with the problem at hand, where each former group has valuable experience and knowledge to contribute, but much of which is of little worth if dealt with in isolation. The changing roles of learners and teachers, the changes of what is an important repertoire for teachers and their sharing of responsibility with other academics are just a few things worth mentioning in this respect. ${ }^{1}$ Teacher Development does not have to wait until after graduating-it can start long before as an evolution from Learner Development.

\section{Note}

1 During the last 10 years several examples of 'cutting through the layers' in the way described in this paper have been carried out as part of teacher development in Iceland. Further information on these activities is available from the author.

\section{References}

Black, P. and Atkin, M. (eds.) Changing the Subject. Innovations in Science, Mathematics and Technology Education. London: Ruthledge in association with OECD.

Cooney, T. (1994). Teacher Education as an Exercise in Adaption. In D Aichele (ed.) Professional Development for Teachers of Mathematics. Reston: The National Council of Teachers of Mathematics.

Finnbogason, G. (1903) Lýdmenntun. Akureyri: Kolbeinn Árnason og Ásgeir Pétursson.

Kieren, T. (1994). Bonuses of Understanding Mathematical Understanding. In D. Robitaille, D. Wheeler and C. Kieran (eds.) Selected Lectures from the $7^{\text {th }}$ International Congress on Mathematical Education. Québec: Les Presses de L'Université Laval.

Noddings, N. (1992). Professionalization and Mathematics Teaching. In D. Grouws (ed.) Handbook of Research on Mathematics Teaching and Learning. New York: Macmillan Publishing Company, 197-208.

Shenitzer, A. (1981). Teaching Mathematics. In L. Steen (ed.) Mathematics Tomorrow. New York: Springer Verlag. 